\title{
Influences of genetic variants on stroke recovery: a meta-analysis of the 31,895 cases
}

\author{
Nikhil Math ${ }^{1} \cdot$ Thang S. Han ${ }^{2,3}$ (D) - Irina Lubomirova ${ }^{1} \cdot$ Robert Hill $^{1} \cdot$ Paul Bentley ${ }^{1,4} \cdot$ Pankaj Sharma ${ }^{2,3,4}$
}

Received: 14 April 2019 / Accepted: 20 July 2019 / Published online: 29 July 2019

(C) The Author(s) 2019

\begin{abstract}
Background The influences of genetic variants on functional clinical outcomes following stroke are unclear. In order to reliably quantify these influences, we undertook a comprehensive meta-analysis of outcomes after acute intracerebral haemorrhage (ICH) or ischaemic stroke (AIS) in relation to different genetic variants.

Methods PubMed, PsycInfo, Embase and Medline electronic databases were searched up to January 2019. Outcomes, defined as favourable or poor, were assessed by validated scales (Barthel index, modified Rankin scale, Glasgow outcome scale and National Institutes of Health stroke scale).

Results Ninety-two publications comprising 31,895 cases met our inclusion criteria. Poor outcome was observed in patients with $\mathrm{ICH}$ who possessed the APOE4 allele: $\mathrm{OR}=2.60(95 \% \mathrm{CI}=1.25-5.41, p=0.01)$ and in AIS patients with the $G A$ or $A A$ variant at the $B D N F-196$ locus: $\mathrm{OR}=2.60(95 \% \mathrm{CI}=1.25-5.41, p=0.01)$ or a loss of function allele of $C Y P 2 C 19: \mathrm{OR}=2.36$ $(95 \% \mathrm{CI}=1.56-3.55, p<0.0001)$. Poor outcome was not associated with APOE4: $\mathrm{OR}=1.02(95 \% \mathrm{CI}=0.81-1.27, p=0.90)$ or $I L 6-174 G / C$ : OR $=2.21(95 \% \mathrm{CI}=0.55-8.86, p=0.26)$ in patients with AIS.

Conclusions We demonstrate that recovery of AIS was unfavourably associated with variants of BDNF and CYP2C19 genes whilst recovery of ICH was unfavourably associated with APOE4 gene.
\end{abstract}

Keywords Polymorphisms $\cdot P O E \cdot B D N F \cdot$ Stroke outcomes

\section{Introduction}

After stroke, the majority of patients achieve fastest recovery by 3 months followed by a deceleration and plateauing

Electronic supplementary material The online version of this article (https://doi.org/10.1007/s10072-019-04024-w) contains supplementary material, which is available to authorized users.

Thang S. Han

thang.han@rhul.ac.uk

Pankaj Sharma

pankaj.sharma@rhul.ac.uk

1 Department of Neuroscience, Imperial College London, South Kensington, London SW7 2AZ, UK

2 Institute of Cardiovascular Research Royal Holloway, University of London, Egham, Surrey TW20 0EX, UK

3 Department of Endocrinology, Ashford \& St Peter's NHS Foundation Trust, Chertsey, England

4 Imperial College Healthcare NHS Trust, London W2 1NY, UK thereafter $[1,2]$. Whilst many factors may influence functional recovery including the size and location of the lesion, delay in treatment and age, these factors do not entirely explain the variability in outcome of stroke [2,3].

Animal studies have demonstrated an influential role for genetics in post-stroke recovery [4]. A number of genes have been implicated which may impact anywhere from a molecular level upwards, culminating in anatomical changes seen with the degree of axonal sprouting and the strength of subsequent adaptive connections [5]. BDNF (brain-derived neurotrophic factor) is one such gene in which its higher concentrations being observed to correlate with favourable outcome in murine models [6].

A previous meta-analysis of stroke patients [7] has been conducted to quantify the specific role of the gene apolipoprotein $\mathrm{E}(A P O E)$ but found no correlation with outcomes in patients recovering from AIS but appeared to associate with worse outcomes in those recovering from ICH (albeit with one study). Hitherto, there has been no attempt to quantify the roles of other genes. We have therefore conducted a meta-analysis to examine the associations of genetic 
variants with functional outcomes in patients recovering from AIS or ICH. To the best of our knowledge, this is the largest such study to date.

\section{Methods}

\section{Literature search}

We searched electronic databases including EMBASE, Medline, PsycINFO and PubMed up to and including January 2019 using search terms 'cerebral infarct', 'stroke', 'brain vascular accident', 'cerebrovascular accident' and 'intracerebral haemorrhage'. Abbreviations (e.g. ICH) and MeSH terms were also searched. The terms 'genetic', 'polymorphism', 'variant', 'variation', 'mutation', 'genotype' or 'phenotype' were searched to identify genetic variants. Stroke outcomes were searched using the terms 'NIHSS', 'Barthel', 'Rankin', 'Glasgow', 'Fugl-Meyer', 'FIM' or 'outcome'. These terms were combined using AND/OR Boolean operators. Additionally, references of all included publications were examined. If multiple publications on the same data were discovered, the largest dataset was selected. Non-English publications were also included.

\section{Selection criteria}

Studies describing patients with different genetic variants and their functional outcome at the latest available time point were included. Where multiple time points were measured, the final point was used. Where investigators did not detail rehabilitation strategies, it was assumed patients received rehabilitation according to local guidelines. Only studies in adults (aged $\geq 18$ years) were selected. Monogenic stroke disorders were excluded as was transient ischaemic attacks and subarachnoid haemorrhage.

\section{Statistical analysis}

Genetic factors including $G A$ or $A A$ variant at the $B D N F$ 196 locus, loss of function allele of CYP2C19, E4 allele and IL6 were used as determinant factors and Barthel index (BI), the modified Rankin scale (mRS), Glasgow Outcome Score (GOS) and the National Institutes of Health Stroke Scale (NIHSS) were used as stroke functional outcomes.

Only variants of the genes APOE, BDNF-196, CYP2C19 and $I L 6$ were examined whilst the remaining genes and polymorphisms were not included due to insufficient number of studies or suitable data. McCarron et al. [8] did not use a validated scale whilst Broderick et al. [9] classified $A P O E$-containing phenotypes differently to the other authors. Where necessary, data were presented with or without the inclusion of these two studies to see if the findings were substantially changed.

The scales used to assess functional outcome of stroke were variable, including the BI which assesses activities of daily living (range $0-100$ ), mRS assesses global disability (range 0-6), GOS assesses the degree of recovery (range 15 ) and NIHSS assesses stroke severity (range $0-42$ ). NIHSS and GOS are usually used immediately whilst mRS and BI are used in the days to months after stroke [10,11]. As a result, only a handful of studies have been conducted to equate these scales [12-14]. In the present study, we relied on the authors' interpretation of 'favourable' or 'poor' outcome based on the particular scale used in their studies. The majority of investigators defined 'favourable' outcome as mRS of $0-1$ or $0-2$ whilst some [8] defined 'favourable' outcome as being one in which the patient was at home at follow-up ( $\mathrm{mRS}=0-4)$ and 'poor' if dead or in care ( $\mathrm{mRS}=5-6)$. Similarly, the BI was defined as follows: 'favourable' $=60-100$ and 'poor' $=0-90$, NIHSS score: 'favourable' $=0-10$ and 'poor' $=2-42$ and GOS: 'favourable' $=5-8$ and 'poor' $=1-4$.

Analysis was performed using data analysed by Review Manager v5.3 (Copenhagen: The Nordic Cochrane Centre, The Cochrane Collaboration, 2014). Pooled odds ratios (OR) were calculated with $95 \%$ confidence intervals (CI) by the random effects model. Inter-study heterogeneity was examined by $I^{2}$ index and studies were iteratively tested to reduce heterogeneity. Funnel plots were used to assess publication bias. Statistical significance threshold was accepted as $p<0.05$.

\section{Results}

Our initial search strategy found 7482 studies, and a total of 92 (comprising 135 polymorphisms in 72 genes) met inclusion criteria (Fig. 1) [8, 9, 15-104]. Characteristics of study populations are described in Supplementary Table 1. and summary of the studies examining the associations between genetic factors and stroke outcomes is shown in Supplementary Table 2.

\section{$A P O E$ variants on functional outcome several months following AIS}

Six studies $[26,43,59,67,82,90]$ comprising 2185 patients (490 with at least one $E 4$ allele and 1695 without) (Fig. 2) showed no association between outcome and the presence of at least one $E 4$ allele: $\mathrm{OR}=1.02(0.81-1.27, p=0.90)$. There was no evidence of inter-study heterogeneity $(p=$ $0.42, I^{2}=1 \%$ ) or publication bias. Including studies by McCarron et al. [8] and Broderick et al. [9] changed the OR to $0.78(0.41-1.47, p=0.44)$. 
Fig. 1 Flow chart of the screening process

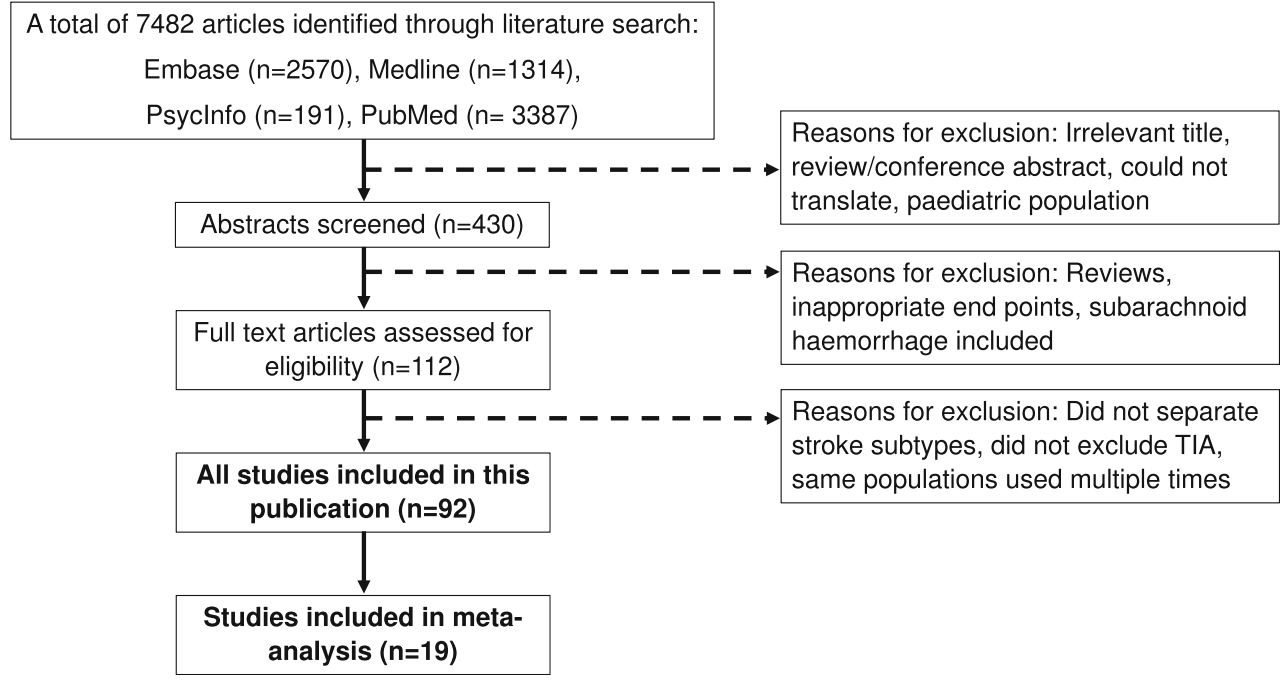

\section{$A P O E$ variants on functional outcome up to several months after an ICH}

Three studies [26, 34, 51] comprising 118 patients (40 with at least one $E 4$ allele and 78 without) (Supplementary Fig. 1) revealed patients with ICH who possessed at least one $E 4$ allele had increased risk of poor outcome: OR 2.45 (1.03-5.81, $p=0.04)$. There was no evidence of inter-study heterogeneity $(p=0.70$, $I^{2}=0 \%$ ) or publication bias. Including the study by McCarron 1998 [8] changed the OR to $2.60(1.25-5.41, p=0.01)$.

\section{BDNF-196 variants on functional outcome up to 7 years following AIS}

In six studies [26, 30, 33, 55, 89, 103] comprising 1241 cases (585 patients with a $G G$ genotype and 656 without) (Fig. 3) showed patients with AIS who carried at codon 196 of the $B D N F$, the $G A$ or $A A$ genotypes were more likely to have poor outcome: OR $1.41(1.02-1.94, p=0.04)$. No heterogeneity $\left(p=0.30, I^{2}=18 \%\right)$ or publication bias was observed. Excluding the study with longest follow-up of 7 years [89] increased the OR to $1.60(1.08-2.37, p=0.02)$.

\section{Cytochrome P450 2C19 (CYP2C19) loss of function variants on functional outcome at 6 months after an AIS}

CYP2C19 polymorphisms (poor metaboliser variants CYP2C19*2, CYP2C19*3 and CYP2C19*17) were studied in three studies comprising 918 patients (446 carried a loss of function allele and 472 without) (Supplementary Fig. 3). Patients with AIS who carried a loss of function CYP2C19 allele were more likely to have poor outcome: $\mathrm{OR}=2.36(1.56-3.55, p<0.0001)$. There was no significant heterogeneity $(p=0.96$, $I^{2}=0 \%$ ) or publication bias.

\section{Interleukin 6-174 (IL-6) variants on functional outcome at 6 months in AIS}

Two studies totalling 237 patients (144 with the $G G$ variant and 93 without) (Supplementary Fig. 4) found no association between patients who carried the $G C$ or $C C$ genotype at codon 176 of IL6 gene and poor outcome: $\mathrm{OR}=2.21(0.55-8.86$, $p=0.26)$.

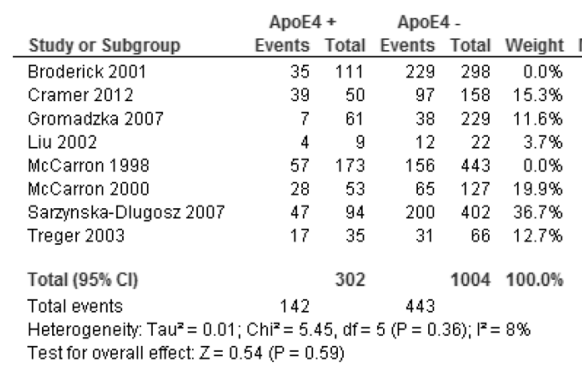

Fig. 2 The odds ratio of having a poor functional outcome up to several months after an AIS with the presence of the ApoE4 allele compared with those without. The random effects model was used to determine the $95 \%$

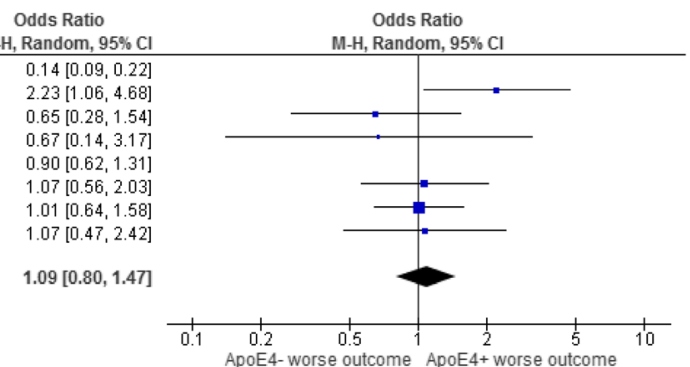

confidence intervals and significance. The blue squares represent the individual studies results and weighting whilst the black diamond shows the overall result 
Fig. 3 Outcome up to 12 months following an AIS with the GG variant at the BDNF-196 locus versus $\mathrm{GA} / \mathrm{AA}$

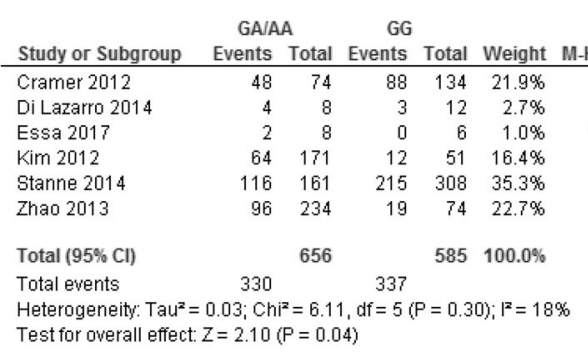

Odds Ratio

Random, $95 \% \mathrm{Cl}$

$0.97[0.53,1.75]$

$3.00[0.45,20.15]$

$5.00[0.20,125.78]$

$1.94[0.95,3.98]$

$1.12[0.73,1.70]$

$2.01[1.12,3.61]$

$1.41[1.02,1.94]$
Odds Ratio M-H, Random, $95 \% \mathrm{Cl}$

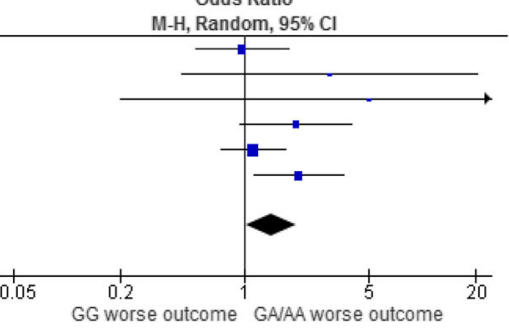

\section{Discussion}

In this meta-analysis, the largest to date, we have shown that genetic influences on functional outcomes in stroke recovery differed between patients who sustained ICH and those who sustained AIS. On the one hand, patients with ICH who possessed APOE4 allele had a 2.6-fold increase in poor outcome; on the other hand, poor outcome was increased among patients with AIS who possessed poor metaboliser variants $(C Y P 2 C 19 * 2, C Y P 2 C 19 * 3$ and $C Y P 2 C 19 * 17)$ by 2.4 -fold and those who carried $B D N F G A$ or $A A$ genotypes by 1.6-fold, but not in patients with AIS who possessed APOE4 or IL6 alleles. Our findings suggest that genetic factors may, in part, account for the variability in stroke recovery and could be served as prognostic markers in the management of stroke.

It is unclear how APOE4 influences poor outcomes in patients recovering from ICH but not in those recovering from AIS but may be linked to its relationship with coagulating ability. Weir et al. [105] have shown that among patients with $\mathrm{ICH}$, compared with non-APOE4 allele carriers, carriers of APOE4 allele had higher partial thromboplastin time (PTT) ratios, i.e. greater propensity to bleed. The same study found that among patients with AIS, increasing APOE4 dose was associated with improved survival independent of stroke severity and PTT.

Similarly, underlying mechanisms on how BDNF-196 variants influence outcomes in patient with AIS remain uncertain. Physical exercise in rehabilitation is thought to increase BDNF levels resulting in a greater capacity for neuronal survival and plasticity after stroke $[103,106]$. However, a metaanalysis in non-stroke patients has shown a lack of association between $B D N F-196$ genotype and serum BDNF levels [107]. Therefore, the association between $B D N F-196$ variation and outcomes is more complex than first thought. The methylation status of the $B D N F$ gene may be important $[55,108]$ and additionally any purported effects are likely to be due to the interplay of multiple polymorphisms at different loci [107].

We observed that loss of function of CYP2C19 was also shown to associate with poor outcome in patient recovering from AIS. This relationship may be explained by a diminished ability of the enzyme to metabolise certain drugs used to treat AIS such as the antiplatelet agent clopidogrel [76, 100] resulting in reduced conversion of prodrug to the active form and efficacy. It has been shown that loss of function of
CYP2C19 allele is time dependent [52]; therefore, the adverse effects on stroke recovery may eventually wear off. However, all these studies were conducted in Chinese patients; therefore, these findings may not be applicable to other populations.

It appears that genes involved with drug metabolism such as MDR1, COX2 and CYP2C19 [52, 62, 71, 76, 83, 85, 100] appear to have major influences on stroke outcome which may be explained by the inflammatory cascade in the recovery process of AIS. Similarly, variants in IL-1, IL-4, IL-6, IL-10 and IL-12 have also been shown to associate with increased levels of inflammatory markers, tissue damage and worse outcomes [18, 22, 42, 66, 97]. In addition, PAI1, FXIII and tPA gene polymorphisms, known to involve in the clotting pathways, can also impact on the degree of thrombosis and the efficacy of fibrinolysis after stroke [36, 41, 62]. Many more mutations in other genes have been identified that have yet to converge with the existing literature.

\section{Limitations}

As with all such analyses, a number of limitations need to be noted. Most papers focus solely on one or two genetic variations, yet it is likely that many such variants work in complex arrangements of gene-gene/gene-phenotype-environment interactions for eventual functional outcomes [100, 109]. For example, people with a family history of cardiovascular disease or risk factors such as hypercholesterolaemia and metabolic syndrome (increased central fat accumulation, hypertriglyceridaemia, low high-density lipoprotein cholesterol, hypertension and hyperglycaemia) may undergo behavioural changes such as intensive lifestyle modification.

The focus of our study was to examine the associations of genetic variants with functional outcomes in patients recovering from AIS or ICH. We recognise that the role of APOE4 allele is more complex, involving small vessel disease, Alzheimer's disease, risk of ICH recurrence and cerebral amyloid angiopathy-related syndromes [110]. However, this topic is beyond the aim of our present study.

Many of the genes described herein appear to correlate with the occurrence and severity of stroke. A more severe stroke usually leads to a worse outcome but this information was not available for our analysis whilst mortality was not consistently included in a number of studies; thus, heterogeneity in individual studies was unavoidable. Like all meta-analyses, 
methodologies between studies often vary; in the present study, we recognise variations in rehabilitation methods, outcome measures, duration of stroke recovery and definition of outcomes varied between papers may influence the degree of association between genetic mutations and stroke recovery but we do not feel the direction of association would be affected. To minimise the variability in outcome measures between studies, we have categorised them as consistently as possible.

The possibility of publication bias cannot be discounted, although funnel plots did not show asymmetrical distribution and we have performed exhaustive literature searches to ensure the maximum coverage. There may be heterogeneity or lack of agreement across scales such that some patients with identical BI scores can have very different $\mathrm{mRS}$ scores, highlighting the subjectivity of the mRS in which bias could potentially be introduced. Furthermore, scales tend to vary at different rates after stroke; therefore, combining scales may only be useful after a certain time, but the 'optimal time' remains undetermined. In contrast to most scales which consist of a wide range of score, mRS suffers from its narrow range of only seven points (0-6). Whilst Govan et al. [14] created an equivalency between the BI, mRS, NIHSS and Scandinavian stroke scale, the remaining studies focused mainly on $\mathrm{mRS}$ and BI. To provide a degree of flexibility when combining the scales in the present study, equivalent categories were created, e.g. a score of $0-3$ on the mRS is equated to $10-20$ on the BI.

In conclusion, we have demonstrated that recovery of AIS was unfavourably associated with variants of $B D N F$ and CYP2C19 genes whilst recovery of ICH was unfavourably associated with E4 allele of $A P O E$ gene. Our findings could be served as prognostic markers in the management of stroke.

Authors' contributions PS and PB reviewed the topic-related literature and performed the study concept and analysis design. NM performed the data collection and wrote the first draft, analysed, interpreted the data. TSH, PS, PB, RH and IL edited and TSH revised the manuscript. All authors checked, interpreted results and approved the final version.

Data Availability No additional data are available.

\section{Compliance with ethical standards}

Competing interests The authors declare that they have no conflicts of interest.

Ethical approval This study does not require NHS Research Ethics Committee approval since it involves secondary analysis of anonymised data. This study was conducted in accordance with the 1964 Helsinki declaration and its later amendments or comparable ethical standards.

Statement of human and animal rights This article does not contain any studies with animals performed by any of the authors.

Provenance and peer review Not commissioned; externally peer reviewed.
Open Access This article is distributed under the terms of the Creative Commons Attribution 4.0 International License (http:// creativecommons.org/licenses/by/4.0/), which permits unrestricted use, distribution, and reproduction in any medium, provided you give appropriate credit to the original author(s) and the source, provide a link to the Creative Commons license, and indicate if changes were made.

\section{References}

1. Maguire J, Bevan S, Stanne T, Lorenzen E, Fernandez-Cadenas I, Hankey G et al (2017) GISCOME - Genetics of Ischaemic Stroke Functional Outcome network: a protocol for an international multicentre genetic association study. Eur Stroke J 2:229-237

2. van de Port IG, Kwakkel G, van Wijk I, Lindeman E (2006) Susceptibility to deterioration of mobility long-term after stroke: a prospective cohort study. Stroke 37(1):167-171

3. Kwakkel G, Kollen BJ (2013) Predicting activities after stroke: what is clinically relevant? Int J Stroke 8(1):25-32

4. Lindgren A, Maguire J (2016) Stroke recovery genetics. Stroke 47(9):2427-2434

5. Overman JJ, Carmichael ST (2014) Plasticity in the injured brain: more than molecules matter. Neuroscientist 20(1):15-28

6. MacLellan CL, Keough MB, Granter-Button S, Chernenko GA, Butt S, Corbett D (2011) A critical threshold of rehabilitation involving brain-derived neurotrophic factor is required for poststroke recovery. Neurorehabil Neural Repair 25(8):740-748

7. Martinez-Gonzalez NA, Sudlow CL (2006) Effects of apolipoprotein $\mathrm{E}$ genotype on outcome after ischaemic stroke, intracerebral haemorrhage and subarachnoid haemorrhage. J Neurol Neurosurg Psychiatry 77(12):1329-1335

8. MCarron MO, Muir KW, Weir CJ, Dyker AG, Bone I, Nicoll JA et al (1998) The apolipoprotein E epsilon4 allele and outcome in cerebrovascular disease. Stroke 29(9):1882-1887

9. Broderick J, Lu M, Jackson C, Pancioli A, Tilley BC, Fagan SC, Kothari R, Levine SR, Marler JR, Lyden PD, Haley EC, Brott T, Grotta JC, NINDS t-PA Stroke Study Group (2001) Apolipoprotein E phenotype and the efficacy of intravenous tissue plasminogen activator in acute ischemic stroke. Ann Neurol 49(6): 736-744

10. Harrison JK, McArthur KS, Quinn TJ (2013) Assessment scales in stroke: clinimetric and clinical considerations. Clin Interv Aging 8:201-211

11. Sulter G, Steen C, De Keyser J (1999) Use of the Barthel index and modified Rankin scale in acute stroke trials. Stroke 30(8): $1538-1541$

12. Wolfe CD, Taub NA, Woodrow EJ, Burney PG (1991) Assessment of scales of disability and handicap for stroke patients. Stroke 22(10): 1242-1244

13. Cioncoloni D, Piu P, Tassi R, Acampa M, Guideri F, Taddei S, Bielli S, Martini G, Mazzocchio R (2012) Relationship between the modified Rankin Scale and the Barthel Index in the process of functional recovery after stroke. NeuroRehabilitation 30(4):315322

14. Govan L, Langhorne P, Weir CJ (2009) Categorizing stroke prognosis using different stroke scales. Stroke 40(10):3396-3399

15. Aberg ND, Olsson S, Aberg D, Jood K, Stanne TM, Nilsson M et al (2013) Genetic variation at the IGF1 locus shows association with post-stroke outcome and to circulating IGF1. Eur J Endocrinol 169(6):759-765

16. Alberts MJ, Graffagnino C, McClenny C, DeLong D, Strittmatter W, Saunders AM, Roses AD (1995) ApoE genotype and survival from intracerebral haemorrhage. Lancet 346(8974):575 
17. Appelboom G, Piazza M, Bruce SS, Zoller SD, Hwang B, Monahan A, Hwang RY, Kisslev S, Mayer S, Meyers PM, Badjatia N, Connolly ES (2012) Variation in a locus linked to platelet aggregation phenotype predicts intraparenchymal hemorrhagic volume. Neurol Res 34(3):232-237

18. Becker KJ, Dankwa D, Lee R, Schulze J, Zierath D, Tanzi P, Cain K, Dressel A, Shibata D, Weinstein J (2014) Stroke, IL-1ra, IL1RN, infection and outcome. Neurocrit Care 21(1):140-146

19. Biffi A, Anderson CD, Jagiella JM, Schmidt H, Kissela B, Hansen BM, Jimenez-Conde J, Pires CR, Ayres AM, Schwab K, Cortellini L, Pera J, Urbanik A, Romero JM, Rost NS, Goldstein JN, Viswanathan A, Pichler A, Enzinger C, Rabionet R, Norrving B, Tirschwell DL, Selim M, Brown DL, Silliman SL, Worrall BB, Meschia JF, Kidwell CS, Broderick JP, Greenberg SM, Roquer J, Lindgren A, Slowik A, Schmidt R, Woo D, Rosand J, International Stroke Genetics Consortium (2011) APOE genotype and extent of bleeding and outcome in lobar intracerebral haemorrhage: a genetic association study. Lancet Neurol 10(8):702-709

20. Bouziana SD, Tziomalos K, Goulas A, Vyzantiadis TA, Panderi A, Etaatzitolios AI (2018) Major adipokines and the $-420 \mathrm{C}>\mathrm{G}$ resistin gene polymorphism as predictors of acute ischemic stroke severity and in-hospital outcome. J Stroke Cerebrovasc Dis 27(4): 963-970

21. Cai H, Cai B, Sun L, Zhang H, Zhou S, Cao L, Guo H, Sun W, Yan B, Davis SM, Zhang Z, Liu X (2017) Association between PTGS1 polymorphisms and functional outcomes in Chinese patients with stroke during aspirin therapy: interaction with smoking. J Neurol Sci 376:211-215

22. Chakraborty B, Chowdhury D, Vishnoi G, Goswami B, Kishore J, Agarwal S (2013) Interleukin-6 gene -174 G/C promoter polymorphism predicts severity and outcome in acute ischemic stroke patients from North India. J Stroke Cerebrovasc Dis 22(5):683-689

23. Chang WH, Park E, Lee J, Lee A, Kim YH (2017) Association between brain-derived neurotrophic factor genotype and upper extremity motor outcome after stroke. Stroke 48(6):1457-1462

24. Cheng X, Xu J, Gu M, Wang M, Sun B, Li Z, Ni G, Wang G, Weng Z, Shi Y, Zhang Z, Liu X (2018) Genetic variants in ALDH2 predict risk of ischemic stroke in a Chinese population. Gene 678:49-54

25. Chon J, Kim HS, Yun DH, Yoo SD, Kim DH, Lee SA, Kim SK, Park HJ, Chung JH, Chung S, Yeo J (2016) Association between a polymorphism (rs2071214) in Baculoviral IAP repeat containing 5 gene (BIRC5) and ischemic stroke in Korean population. Ann Rehabil Med 40(3):392-400

26. Cramer SC, Procaccio V (2012) GAIN Americas, GAIN International Study Investigators. Correlation between genetic polymorphisms and stroke recovery: analysis of the GAIN Americas and GAIN International Studies. Eur J Neurol 19(5): 718-724

27. Dardiotis E, Hadjigeorgiou GM, Dardioti M, Scarmeas N, Paterakis K, Aggelakis K, Komnos A, Tasiou A, Xiromerisiou G, Gabranis I, Zintzaras E, Papadimitriou A, Karantanas A (2008) Alpha-1 antichymotrypsin gene signal peptide a/t polymorphism and primary intracerebral hemorrhage. Eur Neurol 59(6):307-314

28. de Boer RGA, Spielmann K, Heijenbrok-Kal MH, van der Vliet R, Ribbers GM, van de Sandt-Koenderman WME (2017) The role of the BDNF Val66Met polymorphism in recovery of aphasia after stroke. Neurorehabil Neural Repair 31(9):851-857

29. Diaz-Maroto Cicuendez I, Fernandez-Diaz E, Garcia-Garcia J, Jordan J, Fernandez-Cadenas I, Montaner J et al (2017) The UCP2-866G/A polymorphism could be considered as a genetic marker of different functional prognosis in ischemic stroke after recanalization. NeuroMolecular Med 19(4):571-578

30. Di Lazzaro V, Pellegrino G, Di Pino G, Corbetto M, Ranieri F, Brunelli N et al (2015) Val66Met BDNF gene polymorphism influences human motor cortex plasticity in acute stroke. Brain Stimul 8(1):92-96

31. El Husseini N, Hoffman BM, Bennett ER, Li YW, Williamson Taylor RA, Hailey CE et al (2018) Association of IL6ST (gp130) polymorphism with functional outcome following spontaneous intracerebral hemorrhage. J Stroke Cerebrovasc Dis 27(1): 125-131

32. Ellul J, Markoula S, Marousi S, Galidi A, Kyritsis AP, Papathanasopoulos P, Georgiou I (2011) Association of endothelial nitric oxide synthase polymorphism G894T with functional outcome in acute stroke patients. Neurol Res 33(8):835-840

33. Essa H, Vasant DH, Raginis-Zborowska A, Payton A, Michou E, Hamdy S (2017) The BDNF polymorphism Val66Met may be predictive of swallowing improvement post pharyngeal electrical stimulation in dysphagic stroke patients. Neurogastroenterol Motil 29(8):e13062

34. Fadel W, El-Seidy E, Abo-El-Safa A, Khalil M, Mohamed E, Fayed H et al (2012) Prognostic value of apolipoprotein E genotyping in primary intracerebral hemorrhage. Egypt J Neurol Psychiat Neurosurg 49(3):289-292

35. Fernandez-Cadenas I, Alvarez Sabin J, Molina CA, Ribo M, Rosell A, Penalba A et al (2006) ApoE genotype influences on efficacy and safety of thrombolytic treatment for ischemic stroke. Neurologia 21(4):176-180

36. Fernandez-Cadenas I, Del Rio-Espinola A, Rubiera M, Mendioroz M, Domingues-Montanari S, Cuadrado E et al (2010) PAI-1 4G/ $5 \mathrm{G}$ polymorphism is associated with brain vessel reocclusion after successful fibrinolytic therapy in ischemic stroke patients. Int $\mathrm{J}$ Neurosci 120(4):245-251

37. French MA, Morton SM, Pohlig RT, Reisman DS (2018) The relationship between BDNF Val66Met polymorphism and functional mobility in chronic stroke survivors. Top Stroke Rehabil 25(4):276-280

38. Fridriksson J, Elm J, Stark BC, Basilakos A, Rorden C, Sen S et al (2018) BDNF genotype and tDCS interaction in aphasia treatment. Brain Stimul 11(6):1276-1281

39. Giannakopoulou E, Ragia G, Marousi S, Ellul J, Manolopoulos VG, Tavridou A (2013) Association of monocyte chemoattractant protein-1 -2518A $>$ G polymorphism with occurrence, severity, and outcome in ischemic stroke. Neurol Sci 34(8):1315-1320

40. Gomez-Sanchez JC, Delgado-Esteban M, Rodriguez-Hernandez I, Sobrino T, de la Ossa N P, Reverte S et al (2011) The human Tp53 Arg72Pro polymorphism explains different functional prognosis in stroke. J Exp Med 208(3):429-437

41. Gonzalez-Conejero R, Fernandez-Cadenas I, Iniesta JA, MartiFabregas J, Obach V, Alvarez-Sabin J et al (2006) Role of fibrinogen levels and factor XIII V34L polymorphism in thrombolytic therapy in stroke patients. Stroke 37(9):2288-2293

42. Gromadzka G, Sarzynska-Dlugosz I, Czlonkowska A (2007) IL1RN intron 2 polymorphism caused by variable number tandem repeats is associated with 1-year outcome in patients with ischaemic stroke. J Neurol Neurosurg Psychiatry 78(2):183-186

43. Gromadzka G, Baranska-Gieruszczak M, Sarzynska-Dlugosz I, Ciesielska A, Czlonkowska A (2007) The APOE polymorphism and 1-year outcome in ischemic stroke: genotype-gender interaction. Acta Neurol Scand 116(6):392-398

44. Gu M, Wang M, Cai B, Cheng X, Li Z, Sun B et al (2018) Chromosome 10q25 polymorphism is associated with susceptibility to large artery atherosclerotic stroke. Gene 691:18-23

45. Guo J, Yu L, Zhang J, Chen N, Zhou M, He L (2014) CRP gene polymorphism predicts post-stroke functional outcome in Han Chinese. Acta Neurol Scand 129(4):263-268

46. He QS, Yang LF, Wang WB, Yuan B, Zhang LY, Guo XJ (2015) Vascular endothelial growth factor gene is associated with hypertensive cerebellar hemorrhage and rehabilitative treatment. Genet Mol Res 14(3):9849-9857 
47. He W, Lu M, Li G, Sun Z, Liu D, Gu L (2017) Methylene tetrahydrofolate reductase (MTHFR) rs868014 polymorphism regulated by miR-1203 associates with risk and short term outcome of ischemic stroke. Cell Physiol Biochem 41(2):701-710

48. He W, Wang Q, Gu L, Zhong L, Liu D (2018) NOX4 rs11018628 polymorphism associates with a decreased risk and better shortterm recovery of ischemic stroke. Exp Ther Med 16(6):52585264

49. Helm EE, Tyrell CM, Pohlig RT, Brady LD, Reisman DS (2016) The presence of a single-nucleotide polymorphism in the BDNF gene affects the rate of locomotor adaptation after stroke. Exp Brain Res 234(2):341-351

50. Hoy A, Leininger-Muller B, Poirier O, Siest G, Gautier M, Elbaz A, Amarenco P, Visvikis S (2003) Myeloperoxidase polymorphisms in brain infarction. Association with infarct size and functional outcome. Atherosclerosis 167(2):223-230

51. James ML, Blessing R, Bennett E, Laskowitz DT (2009) Apolipoprotein E modifies neurological outcome by affecting cerebral edema but not hematoma size after intracerebral hemorrhage in humans. J Stroke Cerebrovasc Dis 18(2):144-149

52. Jia DM, Chen ZB, Zhang MJ, Yang WJ, Jin JL, Xia YQ, Zhang CL, Shao Y, Chen C, Xu Y (2013) CYP2C19 polymorphisms and antiplatelet effects of clopidogrel in acute ischemic stroke in China. Stroke 44(6):1717-1719

53. Jing M, Li B, Hou X, Shoba J, Li C, Liang H, Zhang X, Liu E, Yang B, Meng X (2013) OPN gene polymorphism and the serum OPN levels confer the susceptibility and prognosis of ischemic stroke in Chinese patients. Cell Physiol Biochem 32(6):1798 1807

54. Keshavarz P, Saberi A, Sharafshah A, Asgari K, Rezaei S (2016) Association of BDNF G196A gene polymorphism with ischemic stroke occurrence and its 6-month outcome in an Iranian population. Top Stroke Rehabil 23(4):254-260

55. Kim JM, Stewart R, Park MS, Kang HJ, Kim SW, Shin IS, Kim HR, Shin MG, Cho KH, Yoon JS (2012) Associations of BDNF genotype and promoter methylation with acute and long-term stroke outcomes in an East Asian cohort. PLoS One 7(12):e51280

56. Lee EJ, Oh MS, Kim JS, Chang DI, Park JH, Cha JK, Heo JH, Sohn SI, Kim DE, Kim HY, Kim J, Seo WK, Lee J, Park SW, Kim YJ, Lee BC (2018) Serotonin transporter gene polymorphisms may be associated with poststroke neurological recovery after escitalopram use. J Neurol Neurosurg Psychiatry 89(3):271-276

57. Li Z, Luo S, Wang F, Zhen J, Sun H, Guo C (2012) An association study between polymorphisms of the fractalkine receptor gene, CX3CR1, and cerebral infarction in the Han Chinese population. J Neurol Sci 320(1-2):12-15

58. Liepert J, Heller A, Behnisch G, Schoenfeld A (2013) Catechol-Omethyltransferase polymorphism influences outcome after ischemic stroke: a prospective double-blind study. Neurorehabil Neural Repair 27(6):491-496

59. Liu Y, Laakso MP, Karonen JO, Vanninen RL, Nuutinen J, Soimakallio S, Aronen HJ (2002) Apolipoprotein E polymorphism and acute ischemic stroke: a diffusion- and perfusionweighted magnetic resonance imaging study. J Cereb Blood Flow Metab 22(11):1336-1342

60. Lovkvist H, Jonsson AC, Luthman H, Jood K, Jern C, Wieloch T et al (2014) Variations in apolipoprotein D and sigma non-opioid intracellular receptor 1 genes with relation to risk, severity and outcome of ischemic stroke. BMC Neurol 14:191-014-0191-2

61. MacLeod MJ, De Lange RP, Breen G, Meiklejohn D, Lemmon H, Clair DS (2001) Lack of association between apolipoprotein E genoype and ischaemic stroke in a Scottish population. Eur J Clin Investig 31(7):570-573

62. Maguire J, Thakkinstian A, Levi C, Lincz L, Bisset L, Sturm J, Scott R, Whyte S, Attia J (2011) Impact of COX-2 rs5275 and rs20417 and GPIIIa rs5918 polymorphisms on 90-day ischemic stroke functional outcome: a novel finding. J Stroke Cerebrovasc Dis 20(2):134-144

63. Malueka RG, Dwianingsih EK, Sutarni S, Bawono RG, Bayuangga HF, Gofir A, Setyopranoto I (2018) The D allele of the angiotensin-converting enzyme (ACE) insertion/deletion (I/D) polymorphism is associated with worse functional outcome of ischaemic stroke. Int J Neurosci 128(8):697-704

64. Manso H, Krug T, Sobral J, Albergaria I, Gaspar G, Ferro JM et al (2010) Variants of the matrix metalloproteinase-2 but not the matrix metalloproteinase-9 genes significantly influence functional outcome after stroke. BMC Med Genet 11:40-2350-11-40

65. Marini S, Devan WJ, Radmanesh F, Miyares L, Poterba T, Hansen BM, Norrving B, Jimenez-Conde J, Giralt-Steinhauer E, Elosua R, Cuadrado-Godia E, Soriano C, Roquer J, Kourkoulis CE, Ayres AM, Schwab K, Tirschwell DL, Selim M, Brown DL, Silliman SL, Worrall BB, Meschia JF, Kidwell CS, Montaner J, FernandezCadenas I, Delgado P, Greenberg SM, Lindgren A, Matouk C, Sheth KN, Woo D, Anderson CD, Rosand J, Falcone GJ, on behalf of the International Stroke Genetics Consortium (2018) 17p12 influences hematoma volume and outcome in spontaneous intracerebral hemorrhage. Stroke 49(7):1618-1625

66. Marousi S, Antonacopoulou A, Kalofonos H, Papathanasopoulos P, Karakantza M, Ellul J (2011) Functional inflammatory genotypes in ischemic stroke: could we use them to predict age of onset and long-term outcome? Stroke Res Treat 2011:792923

67. McCarron MO, Muir KW, Nicoll JA, Stewart J, Currie Y, Brown K et al (2000) Prospective study of apolipoprotein E genotype and functional outcome following ischemic stroke. Arch Neurol 57(10):1480-1484

68. Mirowska-Guzel D, Gromadzka G, Czlonkowski A, Czlonkowska A (2012) BDNF -270 C>T polymorphisms might be associated with stroke type and BDNF $-196 \mathrm{G}>\mathrm{A}$ corresponds to early neurological deficit in hemorrhagic stroke. J Neuroimmunol 249(1-2):71-75

69. Mirowska-Guzel D, Gromadzka G, Seniow J, Lesniak M, Bilik M, Waldowski K et al (2013) Association between BDNF-196 $\mathrm{G}>\mathrm{A}$ and BDNF-270 $\mathrm{C}>\mathrm{T}$ polymorphisms, BDNF concentration, and rTMS-supported long-term rehabilitation outcome after ischemic stroke. NeuroRehabilitation 32(3):573-582

70. Mirowska-Guzel D, Gromadzka G, Mendel T, Janus-Laszuk B, Dzierka J, Sarzynska-Dlugosz I, Czlonkowski A, Czlonkowska A (2014) Impact of BDNF -196 G>A and BDNF -270 C > T polymorphisms on stroke rehabilitation outcome: sex and age differences. Top Stroke Rehabil 21(Suppl 1):S33-S41

71. Munshi A (2012) Genetic variation in MDR1, LPL and eNOS genes and the response to atorvastatin treatment in ischemic stroke. Hum Genet 131(11):1775-1781

72. Murthy SB, Levy AP, Duckworth J, Schneider EB, Shalom H, Hanley DF, Tamargo RJ, Nyquist PA (2015) Presence of haptoglobin-2 allele is associated with worse functional outcomes after spontaneous intracerebral hemorrhage. World Neurosurg 83(4):583-587

73. Olsson S, Jood K, Blomstrand C, Jern C (2011) Genetic variation on chromosome 9p21 shows association with the ischaemic stroke subtype large-vessel disease in a Swedish sample aged $</=70$. Eur J Neurol 18(2):365-367

74. Park HK, Jo DJ (2011) Polymorphisms of integrin, alpha 6 contribute to the development and neurologic symptoms of intracerebral hemorrhage in korean population. J Korean Neurosurg Soc 50(4):293-298

75. Park HK, Kim MC, Kim SM, Jo DJ (2013) Assessment of two missense polymorphisms (rs4762 and rs699) of the angiotensinogen gene and stroke. Exp Ther Med 5(1):343-349

76. Qiu LN, Sun Y, Wang L, Han RF, Xia XS, Liu J, Li X (2015) Influence of CYP2C19 polymorphisms on platelet reactivity and 
clinical outcomes in ischemic stroke patients treated with clopidogrel. Eur J Pharmacol 747:29-35

77. Ragia G, Marousi S, Ellul J, Manolopoulos VG, Tavridou A (2013) Association of functional VKORC1 promoter polymorphism with occurrence and clinical aspects of ischemic stroke in a Greek population. Dis Markers 35(6):641-646

78. Ramos-Araque ME, Rodriguez C, Vecino R, Cortijo Garcia E, de Lera AM, Sanchez Barba M et al (2018) The neuronal ischemic tolerance is conditioned by the Tp53 Arg72Pro polymorphism. Transl Stroke Res 10(2):204-215

79. Ritarwan K, Amir D, Sembiring R, Sadewa A, Lelo A (2014) Outcomes of ischemic stroke and $-455 \mathrm{G} / \mathrm{A}$ beta fibrinogen gene polymorphism. Int J Pharm Res Health Sci 2(6):420

80. Rodriguez C, Sobrino T, Agulla J, Bobo-Jimenez V, RamosAraque ME, Duarte JJ et al (2017) Neovascularization and functional recovery after intracerebral hemorrhage is conditioned by the Tp53 Arg72Pro single-nucleotide polymorphism. Cell Death Differ 24(1):144-154

81. Rodriguez C, Ramos-Araque ME, Dominguez-Martinez M, Sobrino T, Sanchez-Moran I, Agulla J et al (2018) Singlenucleotide polymorphism $309 \mathrm{~T}>\mathrm{G}$ in the MDM2 promoter determines functional outcome after stroke. Stroke 49(10):2437-2444

82. Sarzynska-Dlugosz I, Gromadzka G, Baranska-Gieruszczak M, Ciesielska A, Czlonkowska A (2007) APOE does not predict poor outcome 1 year after ischemic stroke. Neurol Res 29(1):64-69

83. Sharma V, Kaul S, Al-Hazzani A, Prabha TS, Rao PP, Dadheech S et al (2012) Association of C3435T multi drug resistance gene-1 polymorphism with aspirin resistance in ischemic stroke and its subtypes. J Neurol Sci 315(1-2):72-76

84. Sharma V, Dadheech S, Kaul S, Jyothy A, Munshi A (2013) Association of ALOX5AP1 SG13S114T/A variant with ischemic stroke, stroke subtypes and aspirin resistance. J Neurol Sci 331(12):108-113

85. Sharma V, Kaul S, Al-Hazzani A, Alshatwi AA, Jyothy A, Munshi A (2013) Association of COX-2 rs20417 with aspirin resistance. J Thromb Thrombolysis 35(1):95-99

86. Shi J, He W, Wang Y, Hua J (2018) Tagging functional polymorphism in 3' untranslated region of methylene tetrahydrofolate reductase and risk of ischemic stroke. Cell Physiol Biochem 46(3): 1019-1026

87. Shiner CT, Pierce KD, Thompson-Butel AG, Trinh T, Schofield PR, McNulty PA (2016) BDNF genotype interacts with motor function to influence rehabilitation responsiveness Poststroke. Front Neurol 7:69

88. Song YL, Wang CJ, Wu YP, Lin J, Wang PL, Du WL et al (2017) Phosphodiesterase 4D polymorphisms associate with the shortterm outcome in ischemic stroke. Sci Rep 7:42914

89. Stanne TM, Tjarnlund-Wolf A, Olsson S, Jood K, Blomstrand C, Jern C (2014) Genetic variation at the BDNF locus: evidence for association with long-term outcome after ischemic stroke. PLoS One 9(12):e114156

90. Treger I, Froom P, Ring H, Friedman G (2003) Association between apolipoprotein E4 and rehabilitation outcome in hospitalized ischemic stroke patients. Arch Phys Med Rehabil 84(7):973976

91. Wang M, Gu M, Li Z, Sun B, Cheng X, Dai Z, Li S, Xiao L, Zhao M, Wang Z, Lin Y, Liu Y, Xu J, Zhang Z, Liu X (2019) HDAC9 polymorphisms predict susceptibility, severity, and short-term outcome of large artery atherosclerotic stroke in Chinese population. J Mol Neurosci 67(1):165-171

92. Wang Y, Cai H, Zhou G, Zhang Z, Liu X (2016) Effect of CYP2C19*2 and $* 3$ on clinical outcome in ischemic stroke patients treated with clopidogrel. J Neurol Sci 369:216-219

93. Weinstein JR, Schulze J, Lee RV, Phillips H, Zierath D, Tanzi P, Shibata D, Cain KC, Becker KJ (2014) Functional polymorphisms in toll-like receptor 4 are associated with worse outcome in acute ischemic stroke patients. Neuroreport 25(8):580-584

94. Wu H, Weng Y, Zheng L, Li H, Gong Q, Fu Y, Zhao J (2016) Polymorphism of the complement 5 gene is associated with large artery atherosclerosis stroke in Chinese patients. Arq Neuropsiquiatr 74(11):881-886

95. Wzorek J, Karpinski M, Wypasek E, Michalski M, Szczudlik A, Malinowski KP et al (2018) Alpha-2-antiplasmin Arg407Lys polymorphism and cryptogenic ischemic cerebrovascular events: Association with neurological deficit. Neurol Neurochir Pol 52(3): 352-358

96. Xia C, Lin S, Yang J, He S, Li H, Liu M, You C (2018) Genetic variations of COL4A1 gene and intracerebral hemorrhage outcome: a cohort study in a Chinese Han population. World Neurosurg 113:e521-e528

97. Yan J, MG J, AM P (2016) Interleukin 6 promoter 174 G/C polymorphisms in acute ischemic stroke: $\mathrm{G}$ allele is protective but not associated with IL-6 levels or stroke outcome. J Neuroimmunol 293:22-27

98. Yang J, Lin S, Zhou J, Wu B, Dong W, Arima H, Liu H, Zhang J, Li J, Liu M, Chengdu Stroke Registry and Nanjing First Hospital Stroke Registry investigators (2014) Genetic variations of MMP9 gene and intracerebral hemorrhage outcome: a cohort study in Chinese Han population. J Neurol Sci 343(1-2):56-59

99. Ye Z, Zhang H, Sun L, Cai H, Hao Y, Xu Z, Zhang Z, Liu X (2018) GWAS-supported CRP gene polymorphisms and functional outcome of large artery atherosclerotic stroke in Han Chinese. NeuroMolecular Med 20(2):225-232

100. Yi X, Lin J, Wang Y, Zhou Q, Wang C, Cheng W, Chi L (2016) Association of cytochrome $\mathrm{P} 450$ genetic variants with clopidogrel resistance and outcomes in acute ischemic stroke. J Atheroscler Thromb 23(10):1188-1200

101. Zhang J, Yin C, Zhang Y, Zhao L, Fu H, Feng J (2013) The role of OLR1 polymorphisms in determining the risk and prognosis of ischemic stroke in a Chinese population. NeuroRehabilitation 32(2):391-396

102. Zhang Y, Liu S, Yue W, Shi Z, Guan Y, Li M, Ji Y, Li X (2017) Association of apolipoprotein E genotype with outcome in hospitalized ischemic stroke patients. Medicine (Baltimore) 96(50): e8964

103. Zhao J, Wu H, Zheng L, Weng Y, Mo Y (2013) Brain-derived neurotrophic factor G196A polymorphism predicts 90-day outcome of ischemic stroke in Chinese: a novel finding. Brain Res 1537:312-318

104. Zhao J, Bai Y, Jin L, Weng Y, Wang Y, Wu H, Li X, Huang Y, Wang S (2017) A functional variant in the 3'-UTR of VEGF predicts the 90-day outcome of ischemic stroke in Chinese patients. PLoS One 12(2): 0172709

105. Weir CJ, McCarron MO, Muir KW, Dyker AG, Bone I, Lees KR et al (2001) Apolipoprotein E genotype, coagulation, and survival following acute stroke. Neurology 57(6):1097-1100

106. Mang CS, Campbell KL, Ross CJ, Boyd LA (2013) Promoting neuroplasticity for motor rehabilitation after stroke: considering the effects of aerobic exercise and genetic variation on brainderived neurotrophic factor. Phys Ther 93(12):1707-1716

107. Terracciano A, Piras MG, Lobina M, Mulas A, Meirelles O, Sutin AR, Chan W, Sanna S, Uda M, Crisponi L, Schlessinger D (2013) Genetics of serum BDNF: meta-analysis of the Val66Met and genome-wide association study. World J Biol Psychiatry 14(8): 583-589

108. Martinowich K, Hattori D, Wu H, Fouse S, He F, Hu Y, Fan G, Sun YE (2003) DNA methylation-related chromatin remodeling in activity-dependent BDNF gene regulation. Science 302(5646): 890-893

109. Manso H, Krug T, Sobral J, Albergaria I, Gaspar G, Ferro JM, Oliveira SA, Vicente AM (2012) Evidence for epistatic gene 
interactions between growth factor genes in stroke outcome. Eur J Neurol 19(8):1151-1153

110. Banerjee G, Carare R, Cordonnier C, Greenberg SM, Schneider JA, Smith EE, Buchem M, Grond J, Verbeek MM, Werring DJ The increasing impact of cerebral amyloid angiopathy: essential new insights for clinical practice. J Neurol Neurosurg Psychiatry 2017;88(11):982-994

Publisher's note Springer Nature remains neutral with regard to jurisdictional claims in published maps and institutional affiliations. 